\title{
EFFECT OF ALUMINA AND GRAPHENE ON MECHANICAL AND TRIBOLOGICAL BEHAVIOUR OF AI-7075 HYBRID COMPOSITE
}

\author{
UDC: 669.717:621.746 \\ Original scientific paper \\ https://doi.org/10.18485/aeletters.2019.4.3.1 \\ Pamarthi Harish $^{1 *}$, Syed Siddiq ${ }^{1}$, Veeranki Mohan Srikanth ${ }^{1}$, S.B.K. Reddy ${ }^{1}$, K. Ch. Kishore Kumar ${ }^{1}$ \\ 1,2,3 Gudlavalleru Engineering College, Gudlavalleru, India-521356
}

\begin{abstract}
:
In this paper the combined effect of alumina and graphene reinforced with aluminum matrix by using stir casting methodology, was evaluated. Hybrid metal matrix composites gives combined results effect of different reinforced aspects when combined with ductile matrix appearance. Both alumina and graphene we are varied by the weight proportions in order to $1 \%, 2 \%$ and $3 \%$ respectively. With increase in the weight percentage the mechanical properties like hardness were increased. Density was reduced. The detailed microstructure evaluation shows the mixing of reinforcement in the matrix. The tribological behaviour of hybrid composite was determined. The graphene agglomeration in the composite increased the hardness by $35 \%$ as compared to the base material. The composite reinforced with $3 \%$ alumina $+3 \%$ graphene recorded highest hardness.
\end{abstract}

\section{INTRODUCTION}

Automobile industry always explore for latest and advanced materials for the enhance properties of present day usage of materials. Because of raw materials don't show always required properties under all working proportions. Aluminum metal matrix hybrid composites (ALMMHC's) are recent and latest materials outcomes from a combination of two or more materials in which incorporate $d$ properties of both the materials can achieved. In the present days there has more interest on the use of metal matrix hybrid composites (MMHC's) due to their superior properties useful everywhere. MMHCs reinforced with alumina powder and graphene powder tend to offer modest enhancement of properties. Among the MMHCs in aluminum alloys reinforced with silver nano particles and graphene powder [1] by using stir casting method.

Moreover, when reinforcement particulates is added to aluminum matrix material, the properties [2] will further enhance, thereby making it an alternative material for so many light weight aspects. Metal-matrix hybrid composites are especially utilized in prototyping for the space shuttle, commercial airliners, defence usage, electronic substrates, bicycles, automobiles and especially aviation industry because of low weighed structures and in a variety of other applications. Aluminum metal matrix hybrid composites, a growing number of applications enhancing the matrix properties [3] like super alloys, titanium, copper, magnesium alloys Like all composites, aluminum-metal matrix hybrid composites are not a individual material but a club of materials whose stiffness, strength, density, thermal and electrical properties can be altered to the required scale. The matrix material, reinforcement type, volume of material, shape of the reinforced particles, the location of the reinforcement, and the fabrication method can all be varied to get enhanced properties [4]. Regardless of variations in the base materials of different composites, aluminum composites offer the advantage of low cost and ecofriendly over most of the metal matrix composites with optimum weight ratio. In addition, they offer an excellent thermal conductivity, high shear 
strength, abrasion resistance, and hightemperature operation, no flammability, minimal attack by fuels and solvents at the edge of less weight and the ability to be formed and treated on conventional equipment. In the present investigation, an Al 7075 was used as the matrix material and alumina and graphene powder as additives. The hybrid metal matrix composite was fabricated by using conventional technique like stir casting methodology [5].

\section{SELECTION OF MATERIALS}

\subsection{Selection of base material}

For fabrication aluminum metal matrix hybrid composites. We are choosing the matrix base material as aluminium alloy Al-7075 as metal matrix hybrid composite. Aluminium alloy Al-7075 as shown in Fig.1. The chemical composition of Al7075 is shown in the below Table 1.

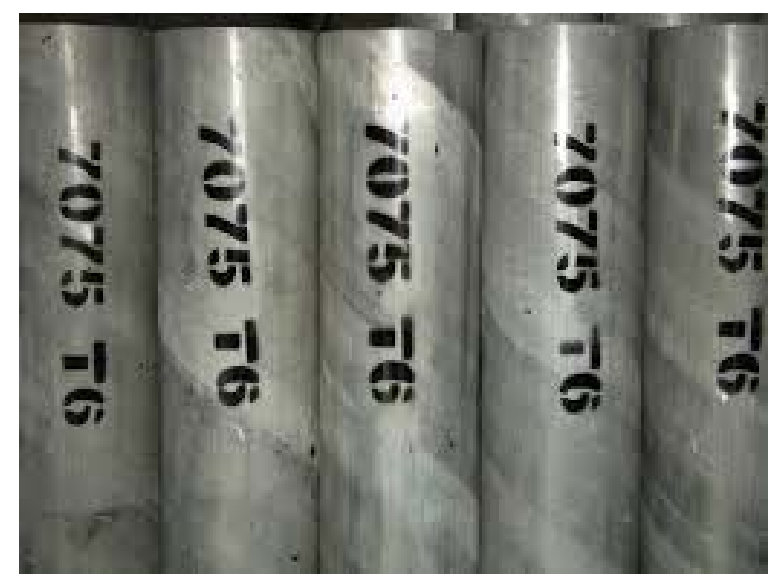

Fig.1. Al-7075

Table 1. Chemical arrangement of Aluminum 7075

\begin{tabular}{|l|l|l|l|l|l|l|l|l|l|}
\hline Comp. & $\mathrm{Cr}$ & $\mathrm{Cu}$ & $\mathrm{Fe}$ & $\mathrm{Mg}$ & $\mathrm{Mn}$ & $\mathrm{Si}$ & $\mathrm{Ti}$ & $\mathrm{Zn}$ & $\mathrm{Al}$ \\
\hline Wt.\% & 0.28 & 2 & 0.5 & 2.9 & 0.3 & 0.4 & 0.2 & 6 & 87 \\
\hline
\end{tabular}

\subsection{Selection of reinforcement}

I am choosing the reinforcements are alumina powder [6] \& Graphene Nano powder as reinforcement material for their properties. Specifications of reinforcements as shown in Table 3. Alumina powder \& Graphene Nano powder as shown in Fig.2 and Fig.3.

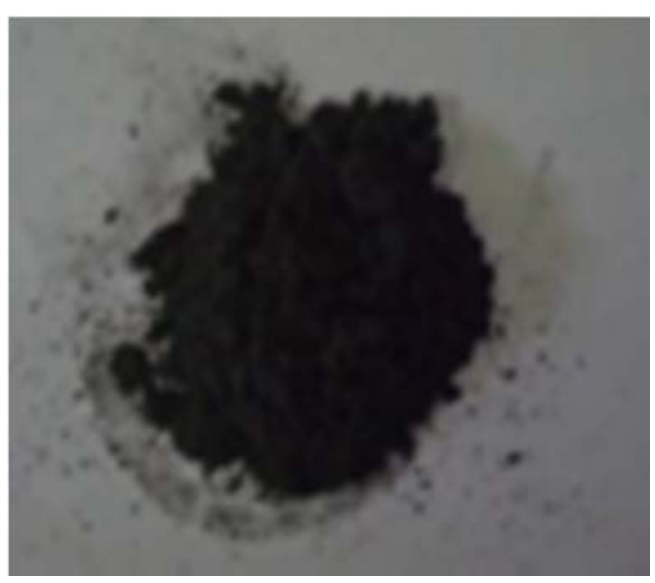

Fig.2. Graphene powder

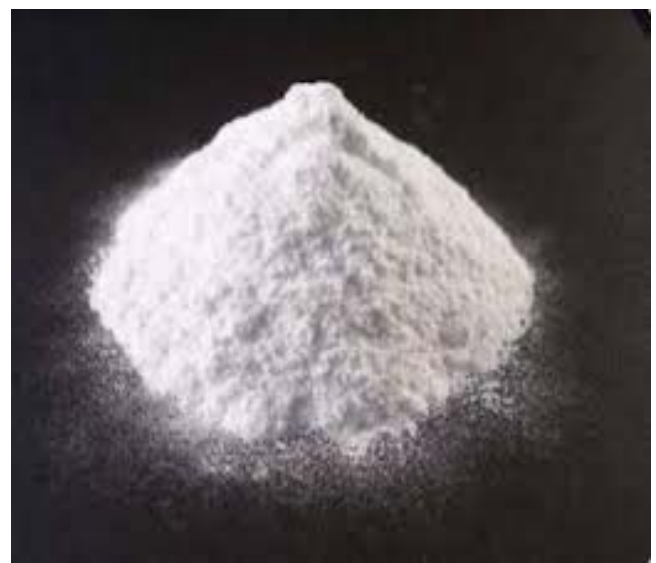

Fig.3. Alumina powder

\subsection{Matrix material}

Al-7075 is an alloy of aluminum association, with zinc as the majority of alloying element in al7075 alloy. It is very strong and tough in strength compared to remaining alloys and many steels and has good fatigue strength, average machinability, [7] high thermal and electrical conductivity, but has lesser resistance to corrosion [8] compared to the other Al alloys. It is utilized in the sporting goods, electronic packaging, armors, defense and automotive industries.

For the fabrication of composite, Al-7075 alloy was utilized to the starting matrix material [9]; whereas low melting additives like namely alumina and Graphene powder were added in pure element form. Properties of Al-7075 as shown in Table 2.

Table-2: Properties of Al-7075

\begin{tabular}{|l|c|c|c|c|c|}
\hline Prop. & Density & $\begin{array}{c}\text { Melting } \\
\text { Point }\end{array}$ & $\begin{array}{c}\text { Tensile } \\
\text { Strength }\end{array}$ & Hardness & Fatigue \\
\hline Valve & $2.81 \mathrm{cc}$ & $483^{\circ} \mathrm{C}$ & $220 \mathrm{Mpa}$ & 147 & $160 \mathrm{Mpa}$ \\
\hline
\end{tabular}




\subsection{Reinforcement materials}

Graphene is an allotrope form carbon including of an individual one layer of carbon atoms are organized in a lattice [10]. But usually for experimental motive up to 6-7 layers of graphemes are permitted .It is semi-metal with a small overlap $\mathrm{b} / \mathrm{t}$ the valence and conduction bands (zero band gap material). It is basic structural element of many other allotropes like carbon, graphite, diamond, charcoal, carbon nano tubes and fullerenes graphene has many uncommon properties. It is the at most strongest material ever determined and tested, with superior heat conductivity and electrical conductive, and is nearly transparent.

Alumina is the regular usual name is aluminum oxide $\left(\mathrm{Al}_{2} \mathrm{O}_{3}\right)$. The alumina is process from the bauxite, an ore. That is mined from top layer of earth soil in different tropical \& subtropical areas. The Bayer process, invented in the year of 1887 , is the initial supreme process by alumina is produced from the bauxite.

Table 3. Specifications of reinforcements \& materials

\begin{tabular}{|c|c|c|c|}
\hline Properties & Al-7075 & Alumina & $\begin{array}{c}\text { Graphene } \\
\text { powder }\end{array}$ \\
\hline $\begin{array}{c}\text { Elastic } \\
\text { Modulus } \\
\text { (Gpa) }\end{array}$ & $70-80$ & 215 & 1000 \\
\hline $\begin{array}{c}\text { Density } \\
\text { (g cc }{ }^{-1} \text { ) }\end{array}$ & 2.81 & 3.95 & $1.61-2.49$ \\
\hline $\begin{array}{c}\text { Poisson's } \\
\text { Ratio }\end{array}$ & 0.33 & 0.21 & $0.17-0.23$ \\
\hline $\begin{array}{c}\text { Hardness } \\
\text { (BHN) }\end{array}$ & 147 & 360 & - \\
\hline $\begin{array}{c}\text { Compressive } \\
\text { Strength (C) } \\
\text { (Mpa) }\end{array}$ & 265 & 690 & 365 \\
\hline
\end{tabular}

\section{EXPRIMENTAL WORK}

\subsection{Stir casting methodology}

$\checkmark$ The bottom pour type of fully advanced censored base Stir-Casting machine Fig.4 is used to fabricate the AMMHCs [11].

$\checkmark$ Initially the base material AL-7075 alloy pieces allowed into the stir casting furnace. The flow chart is shown in Fig. 5.

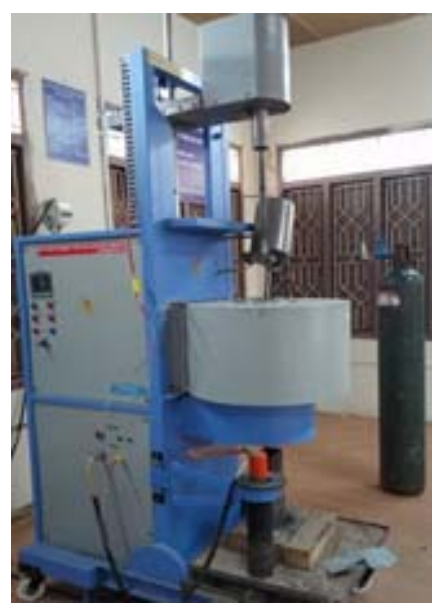

Fig.4. Stir casting machine
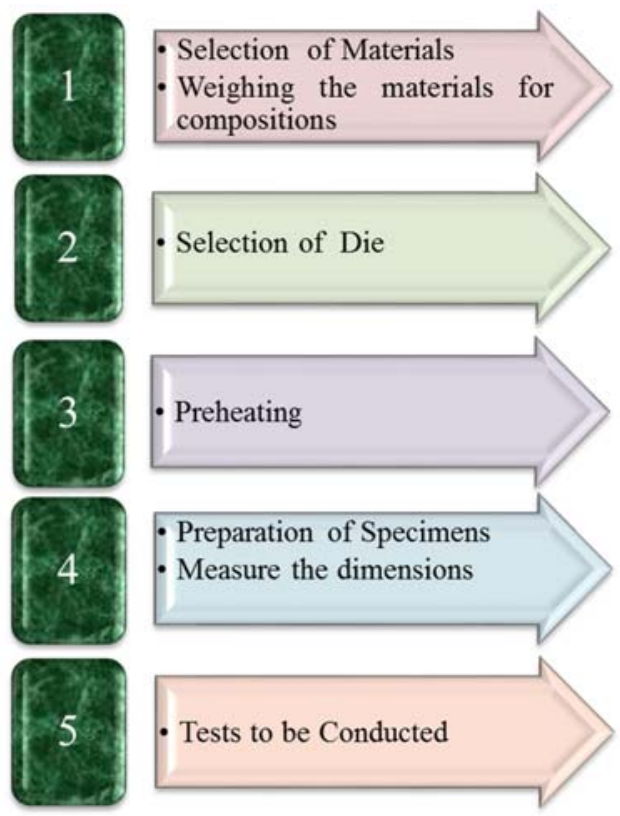

Fig.5. Flow Chart

$\checkmark$ The furnace temperature maintained around $850^{\circ} \mathrm{C}$ centigrade. The matrix base material AL7075 is above $750^{\circ} \mathrm{C}$ temperature of material enhance at most liquid stage.

$\checkmark$ Then 8 grams of $\mathrm{C}_{2} \mathrm{Cl}_{6}$ is included for degasifying the molt melt, and maintains the organ environment with help of oxygen free organ gas [12].

$\checkmark$ Earlier than stirring, the reinforcement is preheated $250^{\circ} \mathrm{C}$ at $50 \mathrm{~min}$, the composition of composite as show in Table 4 . The stirring is done by using mechanical stirrer and the stirrer speed was maintained at $800 \mathrm{rpm}$ and stirring time at $480 \mathrm{sec}$.

$\checkmark$ And it's stirrer is dipped $1 / 3$ of height of molten metal over the furnace, as shown in Fig.6. 
Table 4. Composite Designations

\begin{tabular}{|c|c|c|c|c|}
\hline $\begin{array}{c}\text { Cast } \\
\text { ing }\end{array}$ & $\begin{array}{c}\text { AL-7075 } \\
\text { gm (\%) }\end{array}$ & $\begin{array}{c}\text { Al- } \\
\mathbf{7 0 7 5} \\
\text { (\%) }\end{array}$ & $\begin{array}{c}\text { Reinforcement } \\
\text { (Alumina + } \\
\text { Graphene } \\
\text { powder) }\end{array}$ & $\begin{array}{c}\text { Reinforc } \\
\text { ement } \\
\text { (\%) }\end{array}$ \\
\hline 1 & 800 & 100 & 0 & 0 \\
\hline 2 & 784 & 98 & 16 & 2 \\
\hline 3 & 768 & 96 & 32 & 4 \\
\hline 4 & 752 & 94 & 24 & 6 \\
\hline
\end{tabular}

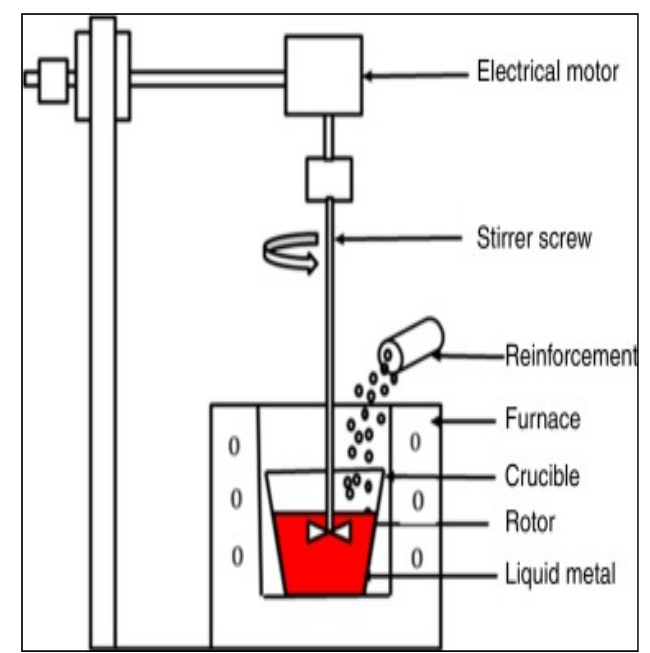

Fig.6. Stir casting methodology

$\checkmark$ During stirring operation both base material AL7075 and reinforcements are mostly mixed. The die was preheated up to $400^{\circ} \mathrm{C}$ at 1.2 hours, Processing Specifications for Stir Casting as shown in Table 5.

$\checkmark$ Finally the molten melt aluminium hybrid composite was transferred into the metallic permanent die.

Table 5. Processing Specifications for Stir Casting [13]

\begin{tabular}{|l|c|c|}
\hline \multicolumn{1}{|c|}{ PARAMETERS } & UNITS & VALUES \\
\hline Spindle speed & Rpm & 800 \\
\hline Stirring time & Seconds & 480 \\
\hline $\begin{array}{l}\text { Stirring temperature of the } \\
\text { molt-melts }\end{array}$ & ${ }^{\circ} \mathrm{C}$ & 750 \\
\hline $\begin{array}{l}\text { Preheating temperatures } \\
\text { of reinforcements }\end{array}$ & ${ }^{\circ} \mathrm{C}$ & 250 \\
\hline $\begin{array}{l}\text { Preheating time of the } \\
\text { Reinforcements }\end{array}$ & $\mathrm{Min}$ & 50 \\
\hline $\begin{array}{l}\text { Preheating temperatures } \\
\text { of die }\end{array}$ & ${ }^{\circ} \mathrm{C}$ & 400 \\
\hline Powder feed rate & $\mathrm{g} / \mathrm{s}$ & $2-2.5$ \\
\hline
\end{tabular}

\subsection{Selection of die}

A Die of two circular rods and a flat plate is as shown in Fig.7 is fabricated for casting process [14]. The dimensions of circular rods are $300 \mathrm{~mm} \times 20$ $\mathrm{mm}$. The dimensions of flat plate were $50 \mathrm{~mm} \times 15$ $\mathrm{mm} \times 100 \mathrm{~mm}$.

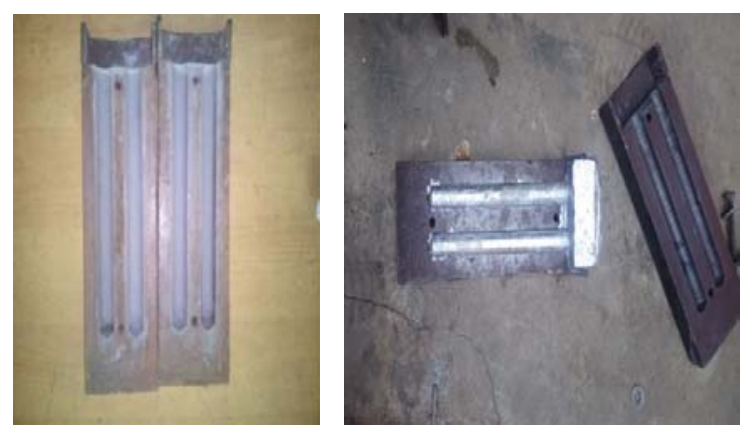

Fig.7. Casting Die

\subsection{Tests conducted}

Tests conducted:

$\checkmark$ Tribological Behaviour,

$\checkmark$ Hardness,

$\checkmark$ Density,

$\checkmark$ Micro structure.

\section{RESULTS AND DISCUSSIONS}

\subsection{Tribological behaviour}

The term tribology is from the science and exercises of interfacing of the surface in a relative actions. It also involves the studies and applications of principle of wear, friction and lubrications. Pinon-disc tester is usage to assess the specific wear of aluminum composite materials through testing of specimens slide the surfaces. These trails was managed under dry laboratory and non-abrasive conditions according to ASTM standards. Schematic figure of the pin-on-disc equipment is shown in Fig.8. The test trails were conducted by apply the basic loads of $15 \mathrm{~N}, 25 \mathrm{~N}$, and $35 \mathrm{~N}$ and various sliding distances of 500,750 and $1000 \mathrm{~m}$ at sliding velocity of $1 \mathrm{~m} / \mathrm{s}$, respectively as shown in Table 6 . The disc was made of EN32 steels with a hardness of HRC 65. The AMMHC specimens were fabricated as pin of circular dimension of $8 \mathrm{~mm}$ diameter with $30 \mathrm{~mm}$ in height as shown in Fig.9. The pins of glide on the disk at a track radius of $30 \mathrm{~mm}$, lower surfaces of test specimens are plane and polished by metallographic alloy before testing. In order to maintain more clear-cut values of the wear rate of 
composite materials, each test trails was completed twice of the specimens.

The effect of wear of Al 7075 hybrid composite at velocity $1 \mathrm{~m} / \mathrm{s}$ as shown in Fig.10. The effect of friction fore of Al 7075 hybrid composite at velocity $1 \mathrm{~m} / \mathrm{s}$ as shown in Fig.11. The wear behaviour at velocity $=1 \mathrm{~m} / \mathrm{s}$ (318 RPM) as shown in Table 7 .

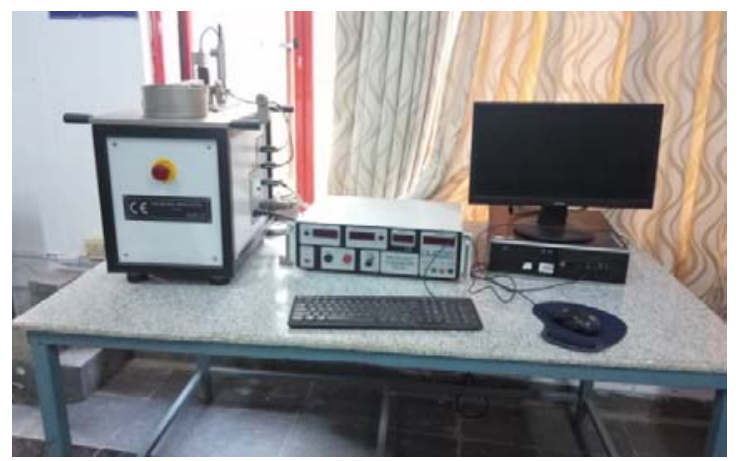

Fig.8. Pin on disc tester

Table 6. Wear test with pin on disc apparatus parameters

\begin{tabular}{|c|c|}
\hline Parameter & Magnitude \\
\hline Size & $8 \mathrm{~mm}$ diameter \\
\hline Load & $15 \mathrm{~N}, 25 \mathrm{~N}, 35 \mathrm{~N}$ \\
\hline Track radius & $30 \mathrm{~mm}$ \\
\hline Velocity & $1 \mathrm{~m} / \mathrm{s}$ \\
\hline Speed & $318 \mathrm{rpm}$ \\
\hline Duration & $08.05 \mathrm{~min}, 11.05 \mathrm{~min}, 16.05 \mathrm{~min}$ \\
\hline Sliding distances & $500 \mathrm{~m}, 750 \mathrm{~m}, 1000 \mathrm{~m}$ \\
\hline
\end{tabular}

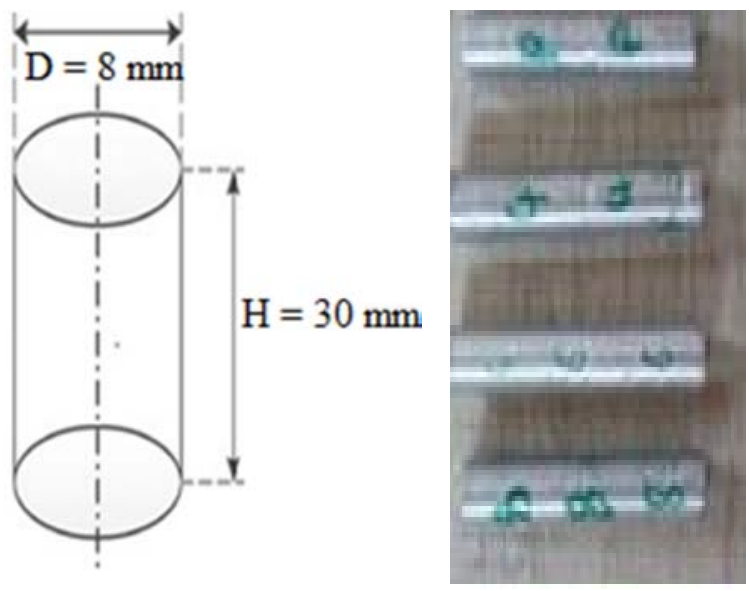

Fig.9. specimens for wear test

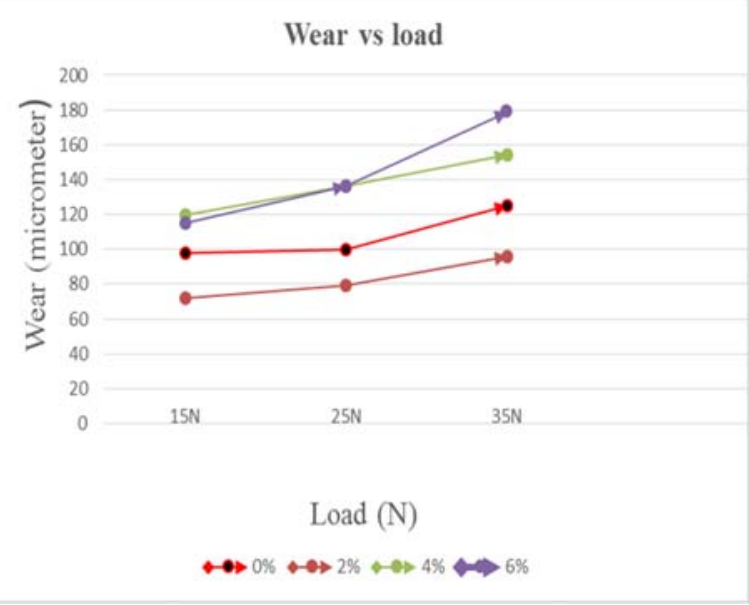

Fig.10. Effect of wear of Al 7075 hybrid composite at velocity $1 \mathrm{~m} / \mathrm{s}$

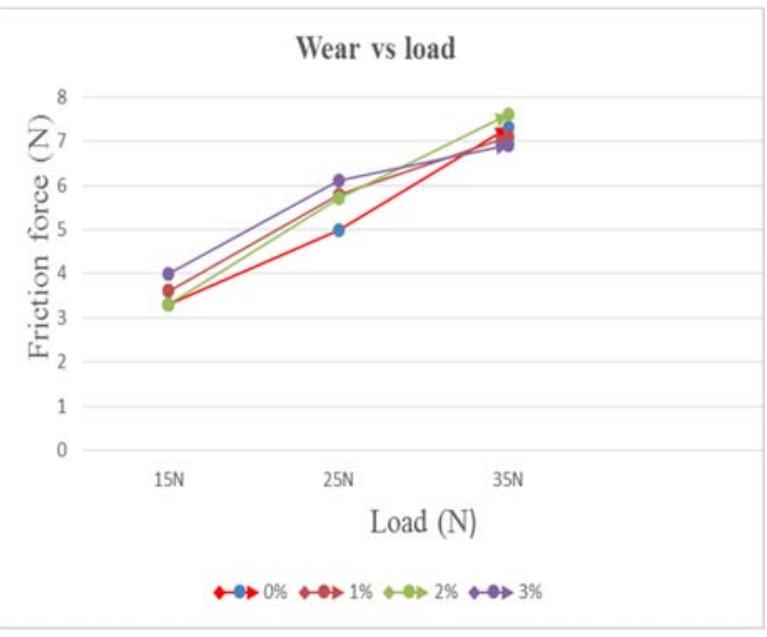

Fig.11. Effect of friction fore Of Al 7075 hybrid composite at velocity $1 \mathrm{~m} / \mathrm{s}$

Table-7: Wear behaviour at velocity $=1 \mathrm{~m} / \mathrm{s}$ (318 RPM)

\begin{tabular}{|c|c|c|c|c|}
\hline \multirow{2}{*}{$\begin{array}{c}\text { Reinforcement } \\
\% \\
\end{array}$} & \multirow{2}{*}{$\begin{array}{l}\text { Load } \\
\text { (N) }\end{array}$} & \multicolumn{3}{|c|}{ wear (micrometer) } \\
\hline & & $5^{\prime} 33^{\prime \prime}$ & $8^{\prime} 18^{\prime \prime}$ & $11^{\prime} 7^{\prime \prime}$ \\
\hline \multirow{3}{*}{$0 \%$} & $15 N$ & 49 & 79 & 98 \\
\hline & $25 N$ & 68 & 87 & 100 \\
\hline & $35 N$ & 74 & 92 & 125 \\
\hline \multirow{3}{*}{$2 \%$} & $15 N$ & 39 & 57 & 72 \\
\hline & $25 N$ & 41 & 48 & 79 \\
\hline & $35 N$ & 44 & 69 & 96 \\
\hline \multirow{3}{*}{$4 \%$} & $15 N$ & 76 & 115 & 120 \\
\hline & $25 N$ & 100 & 110 & 136 \\
\hline & $35 N$ & 110 & 150 & 154 \\
\hline \multirow{3}{*}{$6 \%$} & $15 N$ & 80 & 109 & 115 \\
\hline & $25 N$ & 69 & 102 & 136 \\
\hline & $35 N$ & 88 & 137 & 179 \\
\hline
\end{tabular}




\subsection{Micro Hardness}

Mechanical properties of AL-7075 hybrid metal matrix composite like micro-hardness of the produced hybrid composites was evaluate by utilizing Vickers hardness tester with the scale of VHN Fig.12 as shown. The pieces fabrication and testing proceedings for the micro-hardness measuring was convey the following of ASTM E-8 standards in those pieces are susceptible to straight load of 100 grams for 10s; multiple hardness tests was evaluated on each pieces for precise results and the averages is taken as the micro-hardness of the fabricated ALMMHC sample specimens as shown in Fig.13. Hardness of Al-7075 hybrid composite as shown in Table 8.

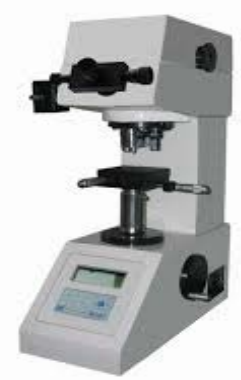

Fig.12. Vickers hardness tester

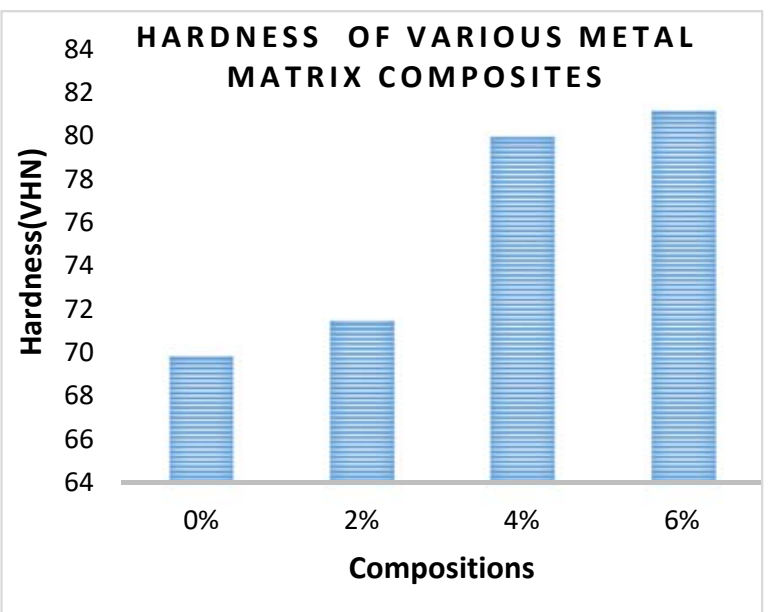

Fig.13. Hardness Graph of Al-7075 Hybrid Composite

Table 8. Hardness of Al-7075 hybrid composite.

\begin{tabular}{|c|c|c|c|c|}
\hline \multirow{2}{*}{$\begin{array}{c}\text { Reinforcement } \\
\mathbf{\%}\end{array}$} & \multicolumn{4}{|c|}{ Hardness(VHP) } \\
\cline { 2 - 5 } & $\begin{array}{c}\text { Trail } \\
\mathbf{1}\end{array}$ & $\begin{array}{c}\text { Trail } \\
\mathbf{2}\end{array}$ & $\begin{array}{c}\text { Trail } \\
\mathbf{3}\end{array}$ & Average \\
\hline $0 \%$ & 74.35 & 66.77 & 68.57 & 69.89 \\
\hline $2 \%$ & 71.19 & 73.9 & 70.48 & 71.52 \\
\hline $4 \%$ & 71.39 & 87.22 & 81.50 & 79.97 \\
\hline $6 \%$ & 81.81 & 81.22 & 79.41 & 81.17 \\
\hline
\end{tabular}

\subsection{Density}

The density of the Al-7075 alloy metal matrix hybrid composite determined was conveyed to the estimate the porosity of the fabricated hybrid metal matrix composites and in order to investigate the effect reinforcement influence of the wt\% proportions of the alumna and grapheme powder of the densities of the produced hybrid metal matrix composites. This was attained by differentiation of the experimental results to theoretical results of the densities of each composition of hybrid composite specimen's proportion weight percent of alumina and grapheme powder reinforced hybrid composites utilizing accepted methodologies. The experimental density ( $\rho$ EXT) was evaluated by tester as shown in Fig.14 dividing the measured weight of the hybrid metal matrix composite pieces by its measured volume by shown in Table 9 . The theoretical density ( $\rho T)$ was obtained by the method of rule of mixtures.

The \% of porosity was evaluated by those relations:

$$
\text { Percentage of Porosity }=\frac{\rho T-\rho E X T}{\rho T} \cdot 100
$$

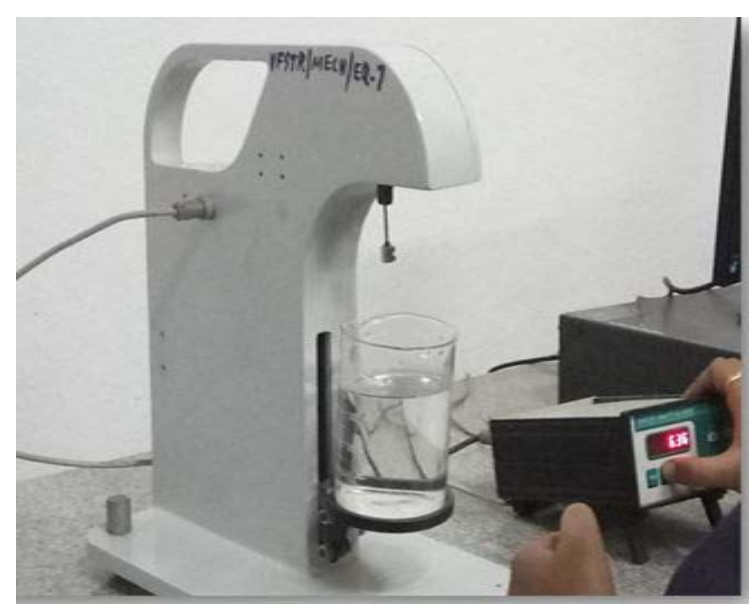

Fig.14. Density Tester

Table 9. Comparison densities of Al-7075 hybrid composite

\begin{tabular}{|c|c|c|c|}
\hline $\begin{array}{c}\text { Specimen } \\
\text { Designations }\end{array}$ & $\begin{array}{c}\text { Theoretical } \\
\text { Densities }\end{array}$ & $\begin{array}{c}\text { Experimental } \\
\text { Densities }\end{array}$ & $\begin{array}{c}\% \\
\text { Porosity }\end{array}$ \\
\hline $0 \%$ & 2.87 & 2.81 & 2.0 \\
\hline $2 \%$ & 2.76 & 2.70 & 2.1 \\
\hline $4 \%$ & 2.50 & 2.45 & 2.0 \\
\hline $6 \%$ & 2.51 & 2.43 & 3.0 \\
\hline
\end{tabular}


The basic methodology of evaluating the density of a pieces by measuring the mass and volume of the pieces was used. The density of the pieces was evaluated from the formula given below and density of specimens as shown in Fig.15. Effect of density Graph of Al 7075 hybrid composite as shown in Fig.16.

$$
\text { Density }\left(\mathrm{g} / \mathrm{cm}^{3}\right)=\frac{\text { Mass }}{\text { Volume }}
$$

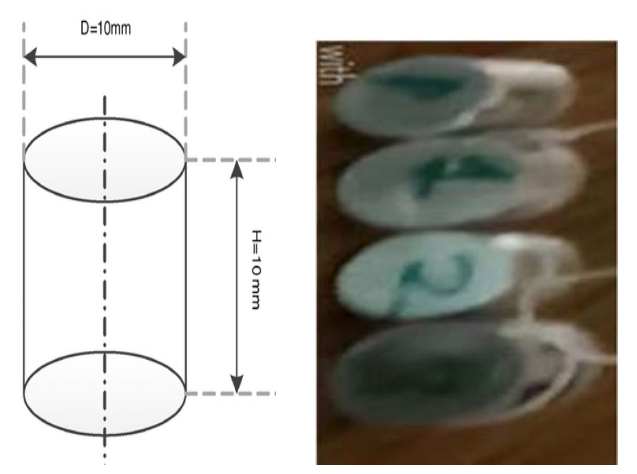

Fig.15. Density Specimens

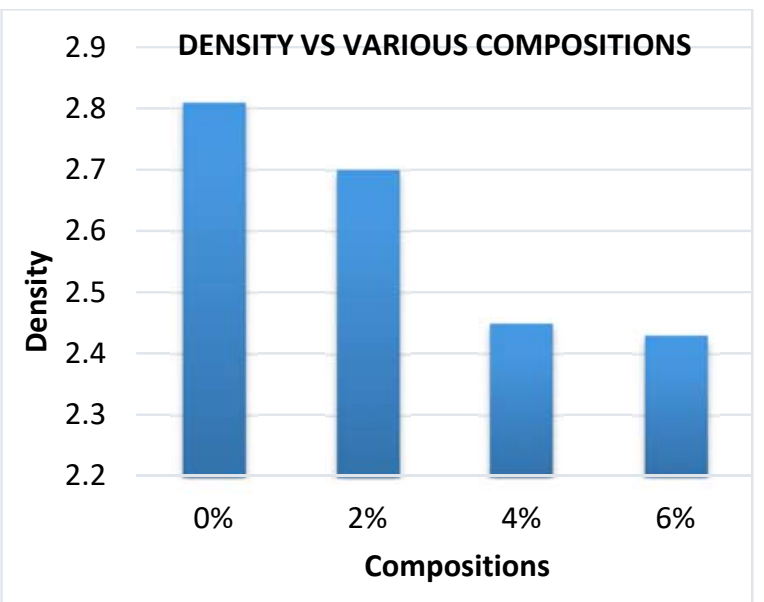

Fig.16. Density Graph of Al 7075 Hybrid Composite

\subsection{Microstructure}

A computerized inverted metallurgical microscope with all accessories to analyse the surface microstructure captures was used to analysis the microstructure of the hybrid metal matrix composites [15]. The micro structure of various metal matrix hybrid composites are as shown in Fig.17 to Fig.20.

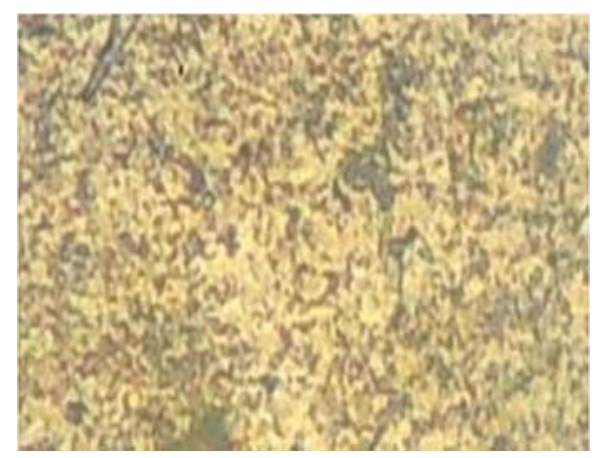

Fig.17. Micro Structure of Al-7075

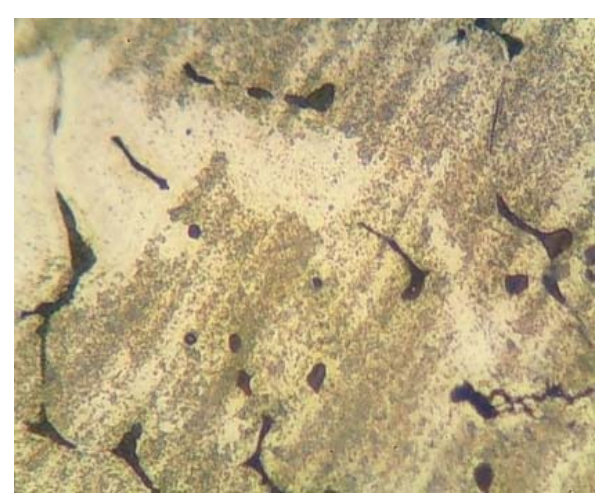

Fig.18. Micro Structure of ALMMHC 2 wt\%

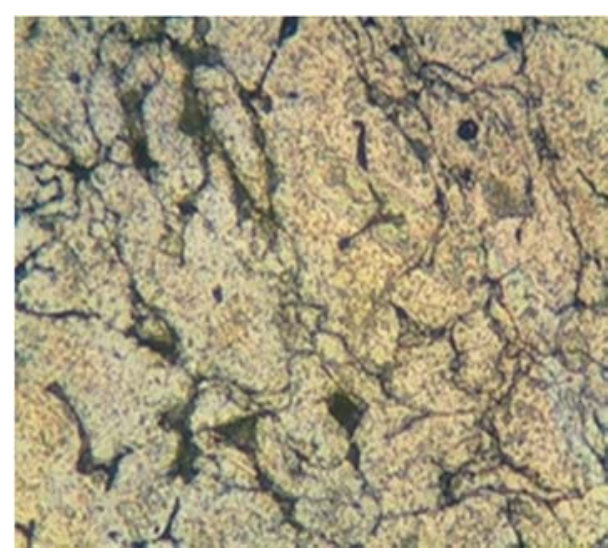

Fig.19. Micro Structure of ALMMHC 4 wt\%

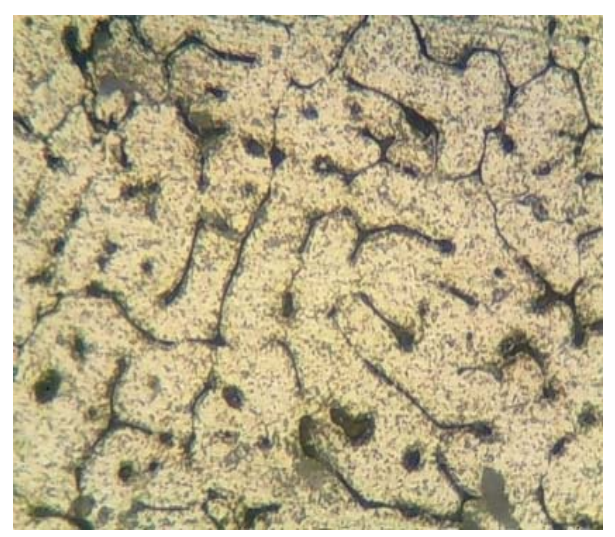

Fig.20. Micro structure of ALMMHC 6 wt\% 


\section{CONCLUSION}

Investigating the effect of alumina and graphene weight $\%$ on the mechanical and tribological behaviour of Al-7075 alloy based hybrid composite containing with several weight portions of $0 \%, 2 \%$, $4 \%$, and $6 \%$ are evaluated to find mechanical, metallurgical and tribological properties such as hardness, density, wear behaviour, and micro structure of aluminium metal matrix hybrid composites (AMMHC).

We have conclude that the reinforcing with alumina and graphene we have the following results:

$\checkmark$ The density of the Al-7075 hybrid composite gradually decreases for all $2 \mathrm{wt} \%, 4 \mathrm{wt} \%$ and 6 wt\% reinforcement of alumna and graphene increases while there as lite significant variations in porosity when compare to previous studies;

$\checkmark$ Improvement of hardness in the AL-7075 alloy by reinforcing alumna and graphene gradually increases differentiate to before work;

$\checkmark$ AL-7075 Hybrid composite containing (1\% of alumna $+1 \%$ of graphene) for both $2 \mathrm{wt} \%$ reinforcement for better wear behaviour. But the wear rate will be increases due to significant change of porosity;

$\checkmark$ Observations from microstructure;

$\checkmark$ Uniform mixing of 2\% of reinforcement, 4\% of reinforcement and $6 \%$ of reinforcement.

Based on the results it can be concluded: the optimum percentage of reinforcement in Al-7075 are $2 \%$ reinforcement such as $1 \mathrm{wt} \%$ of alumna and 1 wt\% of graphene are better mechanical, metallurgical properties and tribological behaviour.

\section{REFERENCES}

[1] M. Darshan, H. N. Reddappa, A. Chandrashekar, R. Vinod Kumar, Mechanical and tribological properties of AA-7075 and graphene reinforced metal matrix composites. International Journal of Science \& Engineering Development Research, 3 (3), 2018: 230-235.

[2] A. Dorri Moghadam, E. Omrani, P. L. Menezes, P. K. Rohatgi, Mechanical and tribological properties of self-lubricating metal matrix nanocomposites reinforced by carbon nanotubes (CNTs) and graphene - A review. Composites Part B: Engineering, 77, 2015: 402420.

https://doi.org/10.1016/i.compositesb.2015.03.014
[3] R. Deaquino-Lara, N. Soltani, A. Bahrami, E. Gutiérrez-Castañeda, E. García-Sánchez, M.A.L. Hernandez-Rodríguez, Tribological characterization of Al7075 - graphite composites fabricated by mechanical alloying and hot extrusion. Materials \& Design, 67, 2015: 224-231.

http://dx.doi.org/10.1016/j.matdes.2014.11.045

[4] M. Tabandeh-Khorshid, E. Omrani, P. L. Menezes, P. K. Rohatgi, Tribological performance of self-lubricating aluminum matrix nanocomposites: Role of graphene nanoplatelets. Engineering Science and Technology, an International Journal, 19 (1), 2016: 463-469.

http://dx.doi.org/10.1016/j.jestch.2015.09.005

[5] H. Kala, K.K.S. Mer, S. Kumar, A Review on Mechanical and Tribological Behaviors of Stir Cast Aluminum Matrix Composites. Procedia Materials Science, 6, 2014: 1951-1960.

https://doi.org/10.1016/i.mspro.2014.07.229

[6] A. Baradeswaran, A. Elaya Perumal, Study on mechanical and wear properties of $\mathrm{Al}$ 7075/Al203/graphite hybrid composites. Composites Part B: Engineering, 56, 2014: 464471.

https://doi.org/10.1016/j.compositesb.2013.08.013

[7] R. Flores-Campos, I. Estrada-Guel, M. MikiYoshida, R. Martínez-Sánchez, J.M. HerreraRamírez, Microstructure and mechanical properties of 7075 aluminum alloy nanostructured composites processed by mechanical milling and indirect hot extrusion. Materials Characterization, 63, 2012: 39-46.

http://dx.doi.org/10.1016/j.matchar.2011.10.014

[8] K. Mohan, J. A. Suresh, P. Ramu, R. Jayaganthan, Microstructure and Mechanical Behavior of Al 7075-T6 Subjected to Shallow Cryogenic Treatment. Journal of Materials Engineering and Performance, 25 (6): 2016: 2185-2194.

https://doi.org/10.1007/s11665-016-2052-1

[9] M. Singla, R. Rana, S. Lata, Microstructure and Mechanical Properties of Aluminium Based Metal Matrix Composite - A Review. International Journal of Advanced Production and Industrial Engineering, 517, 2017: 107109.

[10] R. Karthigeyan, G. Ranganath, S. Sankaranarayanan, Mechanical Properties and Microstructure Studies of Aluminium (7075) Alloy Matrix Composite Reinforced with Short Basalt Fibre. European Journal of Scientific Research, 68 (4), 2012: 606-615. 
[11] P. Harish, V. M. Srikanth, S.B.K Reddy, S. Srikatnh, K. Ch. Kishore Kumar, Mechanical Properties and Tribological Behavior of Stir Cast Al-6063 Alloy Based Hybrid Composite. Journal of Advancements in Material Engineering, 4 (2), 2019: 23-32.

[12] P.Harish, V. M. Srikanth, K. Ch. Kishore Kumar, P. R. Babu, Characterization of Stir Cast Al6063 Alloy Based Hybrid Composite Reinforced With Quarry Dust, Fly Ash and SIC. Journal of Mechanical and Mechanics Engineering, 5 (2), 2019: 32-41.

[13] P. Harish, V. M. Srikanth, P. R. Babu, M. R. Ch. Sastry, K. Ch. Kishore Kumar, Characterization of Mechanical and Tribological Properties of Aluminium alloy based Hybrid Composites
Reinforced with Cotton Shell Ash and Silicon Carbide. International Journal of Latest Engineering Science, 2 (4), 2019: 1-15.

[14] P. Harish, V. M. Srikanth, P. R. Babu, M. R. Ch. Sastry, Investigating the Influence of Cotton Shell Ash- SI,C Weight Percentage on the Mechanical Behaviour of Aluminium Alloy Based Hybrid Composite, International Journal for Research in Applied Science \& Engineering Technology, 7 (V), 2019.

[15] S. Siddiq, S.B.K. Reddy, P. Murari, Effect of Silver nano Particle and Graphene Powder on Mechanical, Micro Structural and Dry Wear Behaviour Properties of Al-7075 Hybrid Nano Composite. IJSART, 5 (6), 2019: 717-725. 